\title{
GGU's aktiviteter i 1992
}

\author{
Martin Ghisler
}

\author{
Direktør
}

De politiske initiativer med henblik på at opnå en større råstofaktivitet i Grønland har også i 1992 præget GGU's arbejde. I løbet af året har der været et internationalt fremstød både i forbindelse med en markedsføring af Grønland som investeringsområde for mineindustrien og i forbindelse med en olieudbudsrunde offshore Vestgrønland syd for $66^{\circ} \mathrm{N}$. På begge områder har GGU, delvis sammen med Råstofforvaltningen, deltaget $i$ internationale messer, kongresser og symposier og specielt arrangerede møder. Her har GGU præsenteret nye områder i Grønland med muligheder for mineralforekomster samt givet orienteringer om oliepotentialet både offshore og onshore Grønland. I forbindelse med olieudbudsrunden offshore Vestgrønland har GGU bistået Råstofforvaltningen med geologisk og geofysisk information og deltaget $i$ det faglige arbejde $i$ forbindelse med forberedelsen og gennemførelsen af udbudsrunden. GGU har til det formål sammenstillet alle relevante geologiske og geofysiske data til brug for olieindustrien. På området for mineralske råstoffer har GGU udover præsentationerne bidraget med skriftligt materiale til internationale særudgivelser om Grønlands mineralpotentiale. Sammen med Råstofforvaltningen er der ligeledes påbegyndt en udsendelse af et 'Newsletter' til mineindustrien med oplysninger og resultater af relevans for mineralefterforskningen (Greenland MINEX News) - en pendant til GHEXIS på kulbrinteområdet, som GGU har udgivet siden 1990.

I årets $l ø b$ har GGU i Råstofforvaltningens regi endvidere deltaget i sagsbehandlingen vedrørende tilsynet med udenlandske mineselskabers aktiviteter i Grønland. Der er ydet rådgivning til Grønlands Energiforsyning i glaciologiske spørgsmål vedrørende vandkraftudnyttelse, og Udenrigsministeriets havretssekretariat er blevet bistået med de geologiske aspekter af sokkelspørgsmål omkring Grønland.

En række forskningsprojekter vedrørende de geologiske forhold i både Vest-, Syd-, Øst- og Nordøstgrønland er blevet gennemført. Disse har dels været af grundvidenskabelig karakter og har dels været mere målrettede råstofundersøgelser. I alt har 59 videnskabelige og tekniske medarbejdere deltaget i GGU's ekspeditioner i 1992. En stab på 85 medarbejdere har været tilknyttet institutionen i København.

\section{Mineralefterforskning}

Med henblik på en vurdering af Sydgrønlands og Sydøstgrønlands mineralpotentiale har GGU igangsat et projekt (projekt SUPRASYD), og her er der blevet udført geologiske, geofysiske og geokemiske unders $\emptyset$ gelser. Med Prins Christian Sund Telestation som udgangspunkt er der udført geologisk rekognoscering på østkysten op til Tingmiarmiut. Af hensyn til korrelation med vest- og sydkysten er der endvidere blevet foretaget studier i udvalgte områder nord og øst for Nanortalik.

De råstoforienterede undersøgelser omfattede geokemisk indsamling af elvsand og -vand på østkysten mellem $60^{\circ} 15^{\prime} \mathrm{N}$ og $62^{\circ} \mathrm{N}$ ledsaget af geofysiske (gravimetriske) opmålinger. Malmgeologiske studier på udvalgte lokaliteter blev kombineret med detaljerèt prøvetagning.

Feltarbejdet inddrog anvendelsen af satellitdata til kontrol og tolkning af geologiske strukturer. På baggrund af satellitbilleder fremstilles geologiske kort $i$ oversigtsmålestok; et arbejdsredskab som hidtil kun i meget beskedent omfang er blevet anvendt i Grønland. Undersøgelserne i Syd- og Sydøstgrønland blev udført i samarbejde med geologer fra England og Canada, og feltarbejdet blev st $ø$ ttet finansielt af Råstofforvaltningen.

Andre undersøgelser på mineralområdet har i løbet af 1992 omfattet geologiske of geokemiske undersøgelser mellem Aasiaat og Maniitsoq/Sukkertoppen. Et $14500 \mathrm{~km}^{2}$ stort område er blevet dækket af en systematisk prøveindsamling af elvsand og -vand med henblik på lokalisering af områder af særlig interesse for mineralefterforskning. I området omkring Svartenhuk Halvø er der foretaget lokale råstofgeologiske og geokemiske undersøgelser. Endvidere er der syd for Aasiaat/Egedesminde og Qasigiannguit/Christianshåb gennemført flybårne målinger af jordens magnetfelt over et område på godt $8000 \mathrm{~km}^{2}$. Resultaterne af disse vil bidrage til en vurdering af områdets strukturer og tilstedeværelsen af eventuelle mineralforekomster. Opmålingen og tolkningen af resultaterne er udført af et canadisk geofysisk selskab i samarbejde med GGU med finansiel støtte fra Råstofforvaltningen og Nunaoil A/S. 


\section{Oliegeologi}

GGU's største enkelte feltaktivitet havde i 1992 lagt hovedvægten på oliegeologisk relaterede unders $\emptyset$ gelser af sedimenterne i området mellem Nuussuaq og Svartenhuk Halvø. Feltarbejdet udgik fra Uummanaq og var afslutningen på et fire-årigt projekt, der er blevet støttet med blandt andet energiforskningsmidler. Det er gennemført i nært samarbejde med geologer og studerende fra universiterne i København og Århus. Sedimentbjergarterne på land er blevet kortlagt og detaljeret undersøgt blandt andet med henblik på en vurdering af muligheder for kildebjergarter $\mathrm{i}$ offshore områderne. Foruden almindelig prøveindsamling blev der på Nuussuaq og Svartenhuk Halvø foretaget 12 kerneboringer med en gennemsnitlig længde pả $67 \mathrm{~m}$ med henblik på at få friskt prøvemateriale til mikropalæontologiske og geokemiske undersøgelser. Under feltarbejdet blev der fundet vidnesbyrd om udsivning af olie i overfladen. I sammenhæng med de oliegeologiske studier blev der gennemført undersøgelser af den vulkanske lagserie på Nuussuaq.

Med finansiel støtte fra Råstofforvaltningen blev der ved hjælp af inspektionsskibet Thetis med Nunaoil A/S som seismisk entrepren $ø$ r indsamlet seismiske data ud for Vestgrønland for GGU i et område mellem $66^{\circ} \mathrm{N} \mathrm{og}$ $68^{\circ} \mathrm{N}$. Der blev indsamlet i alt 3017 liniekilometer seismik som led i de regionale oliegeologiske unders $\varnothing$ gelser af undergrunden.

I Østgrønland udf $\varnothing r t e s$ i samarbejde med Københavns Universitet detailundersøgelser af udvalgte profiler i Jameson Land med henblik på, at få en bedre forståelse af de faktorer, der styrer aflejringen af reservoir- og kildebjergarter.

\section{Glaciologiske undersøgelser}

GGU's glaciologiske undersøgelser omfattede i 1992 dels en række vandkraft relaterede undersøgelser, dels forskellige klimaforskningsprojekter. Som et led i den løbende vurdering af vandkraftmulighederne i Grønland, blev de glaciologiske undersøgelser syd for Nuuk/ Godthåb videreført. I Sydgrønland, nordøst for Qaqortoq/Julianehåb, foretoges i samarbejde med Grønlands Energiforsyning og Grønlands Forundersøgelser indle- dende studier. Nord for Ilulissat/Jakobshavn afsluttede GGU sine vandkraftundersøgelser på indlandsisen, og samme sted blev der gennemført unders $\varnothing$ gelser i forbindelse med deltagelse $i$ et internationalt klimaforskningsprojekt støttet af EF. Glaciologiske unders $ø$ gelser i forbindelse med internationale klimaforskningsprojekter blev endvidere gennemført syd for Kangerlussuaq/ Søndre Strømfjord i samarbejde med et amerikansk forskerhold. I Nordøstgrønland blev der udført undersøgelser i samarbejde med og støttet af Alfred Wegener Institutet i Tyskland og Kommissionen for Videnskabelige Undersøgelser i Grønland samt Dansk Polarcenter.

\section{Andre forskningsopgaver}

I forbindelse med det internationale videnskabelige Ocean Drilling Program (ODP) blev der på den østgrandlandske shelf ud for Tasiilaq/Ammassalik foretaget seismiske undersøgelser i samarbejde med Århus Universitet og Danmarks Geologiske Undersøgelse og finansieret af Statens Naturvidenskabelige Forskningsråd: For at forberede boringer i området i 1993 og eventuelt i 1994, blev der indsamlet $2800 \mathrm{~km}$ 'shallow' seismiske data. Projektet skal kortlægge bjergarterne under havbunden og belyse de vulkanske og tektoniske processer, der førte til åbningen af Atlanterhavet.

Nær Danmarkshavn foretoges detailunders $\emptyset$ gelser af højtryksomdannede bjergarter (eclogiter) i samarbejde med en geolog fra New York State Geological Survey. Den store udbredelse af denne eclogit-provins blev først opdaget under GGU's expedition til Nordøstgrønland i 1990.

\section{Publikationer}

I 1992 har GGU udgivet et geologisk specialkort fra $\emptyset$ stgrønland mellem $72^{\circ} 25^{\prime} \mathrm{N}$ og $74^{\circ} 30^{\prime} \mathrm{N}$ i skala $1: 250000$ samt en kortbladsbeskrivelse vedrørende Nordgrønland (blad $7 \operatorname{og} 8$ ). Der er udkommet to bulletiner, seks bind i rapport-serien samt 10 bidrag til Open File-serien foruden en geologibog på grønlandsk i GGU's populærvidenskabelige serie. Som resultat af GGU's aktiviteter er der desuden publiceret 24 artikler $\mathrm{i}$ internationale fagtidsskrifter. 